\title{
Diversity and prevalence of antiretroviral genotypic resistance mutations among HIV-1-infected children
}

\author{
FLÁVIA J. ALMEIDA ${ }^{1}$, EITAN N. BEREZIN² ${ }^{2}$ ROSÂNGELA RODRIGUES ${ }^{3}$, \\ MARCO A. P. SÁFADI ${ }^{4}$, MARIANA V. ARNONI ${ }^{5}$, CRISTINA OLIVEIRA ${ }^{6}$, LUIS F. M. BRÍGIDO \\ 1. Médica assistente, Serviço de Infectología Pediátrica, Santa Casa de São Paulo, São Paulo, SP, Brazil. \\ 2. Médico responsável, Serviço de Infectología Pediátrica, Santa Casa de São Paulo, São Paulo, SP, Brazil. \\ 3. Médica responsável, Laboratório de Genotipagem, Instituto Adolfo Lutz, São Paulo, SP, Brazil. \\ 4. Médico assistente, Serviço de Infectología Pediátrica, Santa Casa de São Paulo, São Paulo, SP, Brazil. \\ 5. Médica pós-graduanda, Faculdade de Ciências Médicas, Santa Casa de São Paulo, São Paulo, SP, Brazil. \\ 6. Biomédica, Laboratório de Genotipagem, Instituto Adolfo Lutz, São Paulo, SP, Brazil. \\ 7. Médico, Laboratório de Genotipagem, Instituto Adolfo Lutz, São Paulo, SP, Brazil.
}

\begin{abstract}
Objective: To evaluate genotyping and subtyping in antiretroviral (ARV) naïve and experienced children, as well as drug resistance profiles through genotyping in these children. Methods: This retrospective study assessed ARV-naïve HIV children and HIV children failing highly active antiretroviral treatment (HAART) followed up at Santa Casa de São Paulo. Genotyping was performed using purified polymerase chain reaction (PCR) products from retrotranscribed RNA using Kit Viroseq HIV-1 Genotyping System 2.0 or nested PCR in-house. Sequencingwas performed using automatic equipment (ABI 3100). ARV resistance mutations were analyzed in the Stanford HIV Drug Resistance Database and subtyping was performed at the National Center for Biotechnology Information (NCBI), using SimPlot analysis, together with phylogenetic analysis. Results: No primary ARV resistance mutation was detected in the 24 ARV-naïve children, although there were mutations that may contribute to resistance to nucleoside analogue reverse transcriptase inhibitors (NRTI) (12.5\%) and to protease inhibitors (PI) (95.8\%). For the 23 children failing HAART, we found ARV resistance mutations to NRTI in 95.6\% and to non-nucleoside analogue reverse transcriptase inhibitors (NNRTI) in 60.8\%. For PI, we found ARV resistance mutations in $95.7 \%, 47.8 \%$ of which had only polymorfisms. In the subtyping analyses, $78.3 \%$ of the sequences clustered in HIV-1 subtype B, $4.3 \%$ in C, $13 \%$ in $\mathrm{F}$ and $4.4 \%$ in recombinant forms. Conclusion: Our results show low rates of primary resistance in ARV-naïve children and high rates of resistance in children failing ARV treatment, which is compatible with ARV use in these patients.
\end{abstract}

(Key words: HIV, resistance, genotype, child, antiretroviral therapy).

J Pediatr (Rio J). 2009;85(2):104-109

ESTE TRABAJO LO PUEDE ENCONTRAR EN EXTENSO EN WWW.SciELO.ORG

Correspondencia a:

Flávia J. Almeida

E-mail: flaviaja@gmail.com 